\title{
Energy content of macrobenthic invertebrates: general conversion factors from weight to energy
}

\author{
Thomas Brey ${ }^{1}$, Heye Rumohr ${ }^{1}$ and Sven Ankar ${ }^{2}$ \\ ${ }^{1}$ Institut für Meereskunde, Kiel, F.R.G. ${ }^{2}$ Askö Laboratory, Institute of Marine Ecology, University of \\ Stockholm, Stockholm, Sweden
}

(Received 16 September 1987; revision received 10 February 1988; accepted 11 February 1988)

\begin{abstract}
In ecological studies, especially in those dealing with energy circulation in nature, determinations of the energy content of organisms are inevitable. Energy determinations are, however, laborious and time-consuming. Average conversion factors based on different species form various areas and seasons may often be a shortcut for overcoming this problem. To establish general energy conversion factors for aquatic invertebrate groups, we used 376 values of $\mathrm{J} \cdot \mathrm{mg}^{-1} \mathrm{DW}$ and 255 values of $\mathrm{J} \cdot \mathrm{mg}^{-1}$ AFDW, representing 308 and 229 species, respectively. The dry-weight-to-energy factors were highly variable both within and between taxonomic groups, e.g.: Porifera, $6.1 \mathrm{~J} \cdot \mathrm{mg}^{-1} \mathrm{DW}$; insect larvae, $22.4 \mathrm{~J} \cdot \mathrm{mg}^{-1} \mathrm{DW}$ (median values). The energy-conversion factors related to AFDW showed a much smaller dispersion with a minimum median value of $19.7 \mathrm{~J} \cdot \mathrm{mg}^{-1}$ AFDW (Ascidiacea) and a maximum of $23.8 \mathrm{~J} \cdot \mathrm{mg}^{-1}$ AFDW (insect larvae). Within taxonomic groups, the $95 \%$ confidence intervals (AFDW) were only a few percent of the median values. The use of energy-conversion factors based on AFDW is preferable due to their lower dispersion. For aquatic macrobenthic invertebrates, a general conversion factor of $23 \mathrm{~J} \cdot \mathrm{mg}^{-1}$ AFDW can be used.
\end{abstract}

Key words: Energy content; Invertebrate; Macrobenthos

\section{INTRODUCTION}

Energy transformation between organisms and circuits of energy in nature are of fundamental interest in ecological studies of terrestrial, limnic, marine, and global ecosystems (e.g., Odum, 1971).

Energy content determinations of living and dead organic matter are, however, time-consuming and often also difficult to perform. Variations in the energy content due to season, taxonomic groups, developmental and reproductive stages, food conditions, environmental differences, and other factors strongly influence the results of the measurements, see, e.g., Slobodkin \& Richman (1961), Prus (1970), Griffiths (1977), Norrbin \& Bamstedt (1984).

Many data on energy content have been published especially during the last decades, and several compilations of these data have been produced in the 1970s. The most extensive one is by Cummins \& Wuycheck (1971), which also includes terrestrial plants and animals. Such compilations are very valuable because they often reduce the need for laborious energy determinations.

Correspondence address: T. Brey, Institut fur Meereskunde, Düsternbrooker Weg 20, 2300 Kiel, F.R.G. 


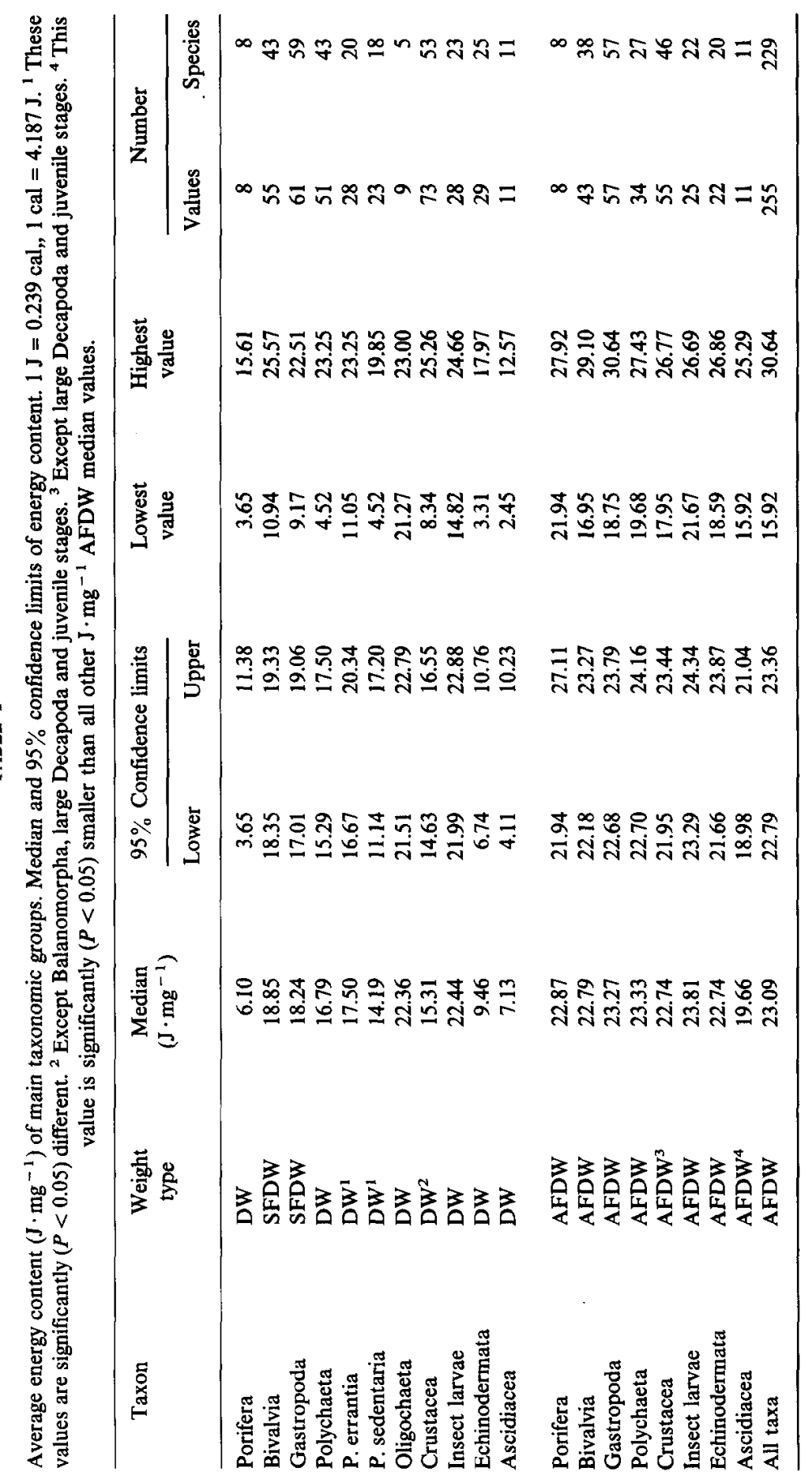


This paper is the spin-off of the work of the Baltic Marine Biologists Working Group 11 (Secondary Production), which recently published a compilation of conversion factors on length-to-weight, weight-to-weight, and weight-to-energy content for Baltic macrobenthic invertebrates (Rumohr et al., 1987).

Here, we present an extended compilation of energy content data limited to the main taxonomic groups of macrozoobenthos. Our aim is to give valid conversion factors from weight to energy, useful for general estimations of energy content and energy flow in aquatic ecosystems.

\section{METHODS}

We searched through the literature available and excerpted most of the energy content data. If a single reference included more than one value per species (e.g., according to different seasons), we calculated a mean value for our compilation. Caloric values were transformed to $\mathrm{J}$.

The following types of energy content data were excluded. (1) Data based on WW and DW of shelled molluscs, because these data were scarce and very scattered. (2) Data based on AFDW, which were not determined by combustion in a muffle furnace, but by subtracting the weight of the residual of bomb calorimetry from DW. (3) Data from taxonomic groups with less than five values available.

Deviation from normal distribution was analysed by means of the KolmogoroffSmirnoff test, differences between data sets were analyzed by means of the nonparametric $U$ test (Wilcoxon, Mann-Whitney), both quoted from Sachs (1978).

\section{RESULTS}

The results are presented in Table 1 at the level of main taxonomic groups. The median is given instead of the arithmetic mean, because some data sets do not show a normal distribution. 376 values of energy-conversion factors based on DW, representing 308 species, and 255 values based on AFDW, representing 229 species are included in the compilation. Approx. $20 \%$ of the species are limnic and the rest is of marine and brackish water origin. The areas of investigation and the methods applied by various authors are listed in Table II.

It is obvious from Table I that there is a much wider range of values both within and between taxonomic groups associated with $\mathrm{J} \cdot \mathrm{mg}^{-1} \mathrm{DW}$ than with $\mathrm{J} \cdot \mathrm{mg}^{-1}$ AFDW. Even within the taxon Polychaeta, we detected significant differences. The conversion factor for the total taxa was, therefore, only calculated on AFDW to energy.

The groups Porifera and Ascidiacea show the lowest energy content values for DW, median values of 6.1 and $7.1 \mathrm{~J} \cdot \mathrm{mg}^{-1} \mathrm{DW}$, the group Ascidiacea shows the lowest value for AFDW, $19.7 \mathrm{~J} \cdot \mathrm{mg}^{-1}$ AFDW. Insect larvae show the highest values, $22.4 \mathrm{~J} \cdot \mathrm{mg}^{-1}$ DW and $23.1 \mathrm{~J} \cdot \mathrm{mg}^{-1}$ AFDW. 


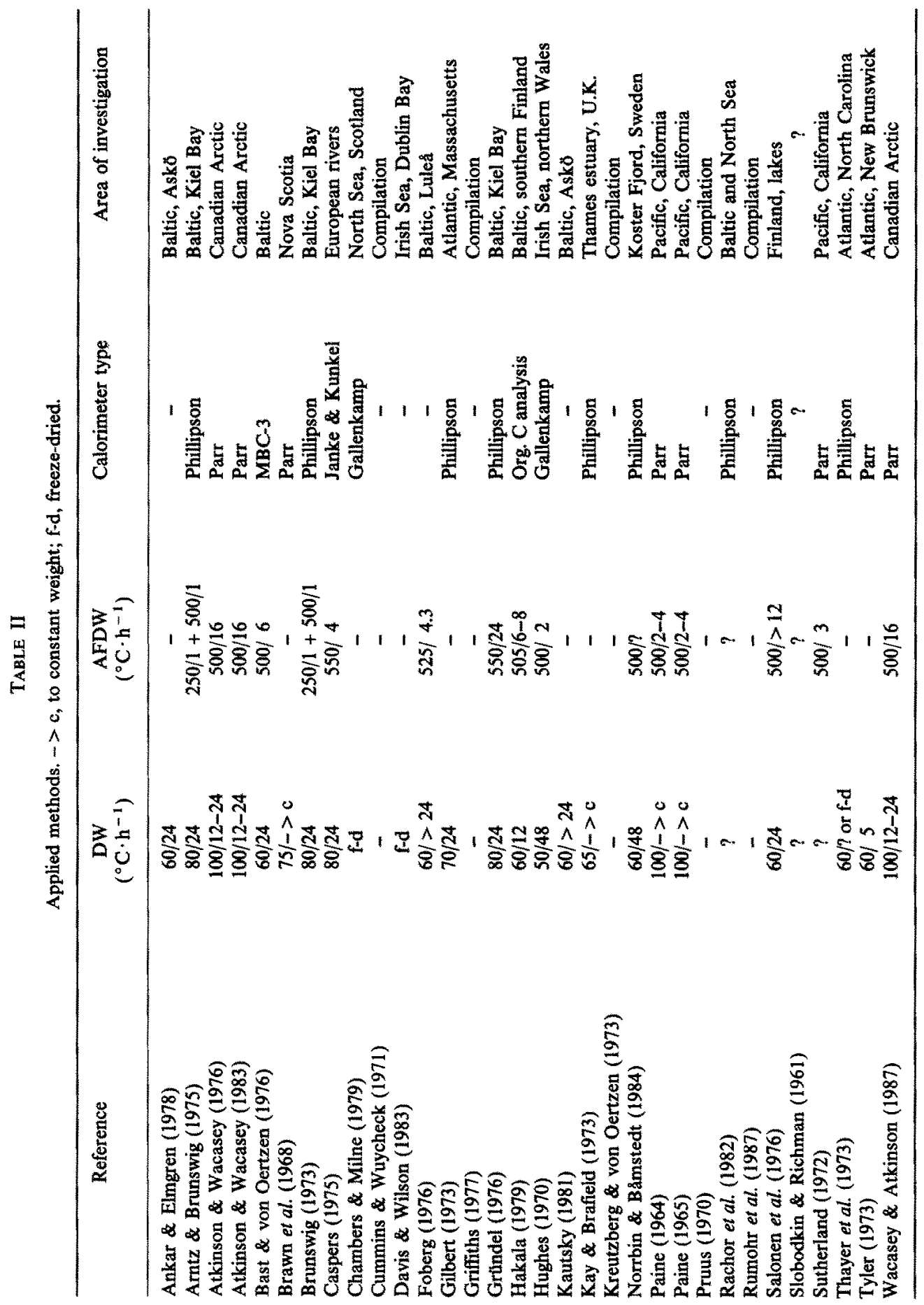


The general median conversion factor from AFDW to energy content is 23.09 $\mathrm{J} \cdot \mathrm{mg}^{-1}$. The distribution of the 255 values included is shown in Fig. 1. This distribution is just significantly different from a normal distribution with mean $=22.99 \mathrm{~J} \cdot \mathrm{mg}^{-1}$ AFDW and variance $=4.42$ (Kolmogoroff-Smirnoff test, $D_{\text {test }}=0.059>D_{\text {tab }}=$ $0.050, \alpha=0.10$ ).

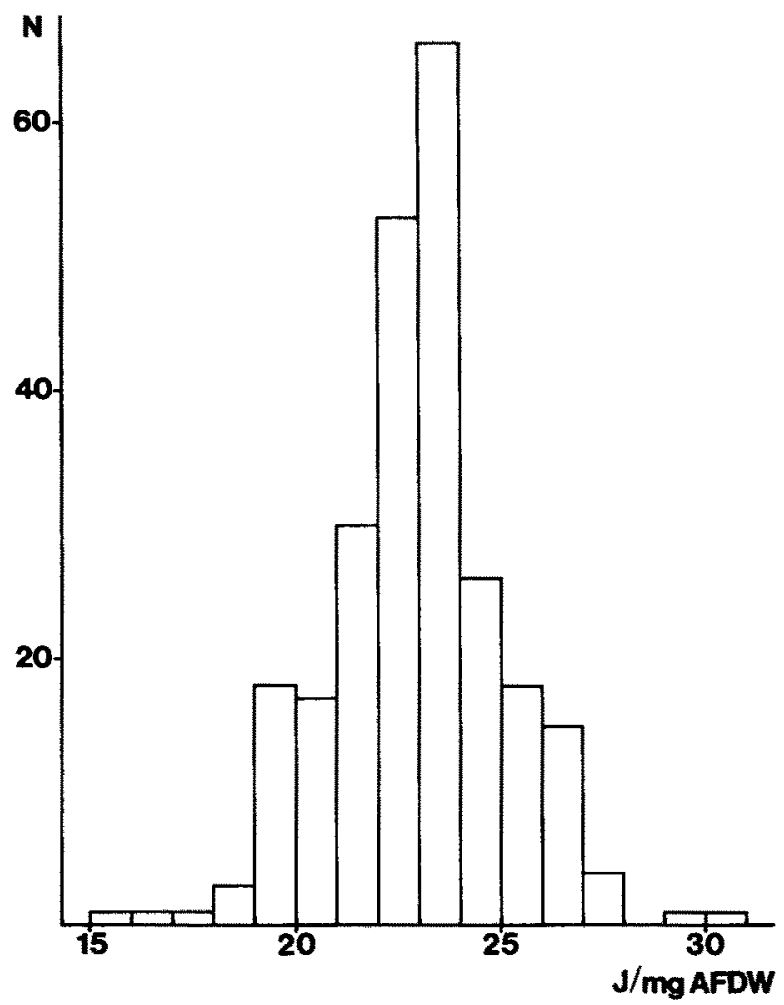

Fig. 1. Distribution of energy content values $\left(\mathrm{J} \cdot \mathrm{mg}^{-1}\right.$ AFDW); 255 values referring to 229 macrobenthic invertebrate species.

\section{Discussion}

The total energetic content of an animal depends on the amount of carbohydrates, proteins, and lipids contained in its body. The energy values of these compounds are $17.16 \mathrm{~J} \cdot \mathrm{mg}^{-1} \mathrm{DW}, 23.65 \mathrm{~J} \cdot \mathrm{mg}^{-1} \mathrm{DW}$, and $39.55 \mathrm{~J} \cdot \mathrm{mg}^{-1} \mathrm{DW}$ (Crisp, 1984). The ratio of these organic components determines the energy content per unit of body mass if inorganic matter is ignored.

The most precise way to determine the energy content of a certain animal is to measure it, e.g., by means of bomb calorimetry or wet oxidation. However, these 
procedures require time and money, and it is quite impossible to perform such measurements frequently during larger ecological surveys.

To simplify the laborious energy determinations, we are looking for an ecologically significant quantity related to animals that should meet at least three certain conditions. (1) The measurement should be simple and fast. (2) There should be a strong correlation between this quantity and the energy content of the animal. (3) This correlation should be independent of season, area and species.

A quantity which meets the first condition, is the body mass of an animal, hence, the aim is to establish an empirical relationship between this body mass and energy content. The most common ways to determine body mass are by wet weight (WW), dry weight (DW), shell-free dry weight (SFDW), ash-free dry weight (AFDW), and organic-carbon weight $\left(\mathrm{C}_{\text {org }}\right)$. The methods are ranked according to the increasing effort needed for the determination (first condition above).

With respect to the second condition, the ranking is reversed because of the decreasing amount of inorganic compounds included in the measurement of weight. The energy content is correlated best to carbon weight (e.g., Salonen et al., 1976), even better than to AFDW.

The narrower range of the AFDW to energy values (both within and between taxa) compared with those of DW to energy and SFDW to energy values indicate a closer correlation between energy content and AFDW than SFDW and DW (Table I).

The third condition is the most troublesome. It is well-known that seasonal changes in the lipid, protein, and carbohydrate content cause great variation in the energy content of benthic species, at least from temperate latitudes (e.g., Hakala, 1979; Davis \& Wilson, 1983). These seasonal variations are often related to different reproductive stages of the animal.

It is quite clear that interspecific differences in energy content do exist (Table I), but they are much smaller when based on $\mathrm{C}_{\text {org }}$ or AFDW. One reason for the greater variation in the energy content related to WW, DW, and SFDW could be due to highly differing amounts of inorganic material in the guts of species of various feeding habits (e.g., filter-feeder vs. nonselective deposit-feeder) or in shells and exoskeletons.

Differences in energy content depend also on general life strategies and environment, e.g., planktonic species have been shown to have a higher average energy content (J· $\mathrm{mg}^{-1}$ AFDW) than benthic species (Griffiths, 1977; Norrbin \& Bamstedt, 1984).

Geographically different races or variants account also for the dispersion in conversion factors. In our compilation, values from wide geographical areas (Atlantic regions of North America and Europe, Pacific regions of North America, brackish and freshwaters of Europe and North America) are included.

As mentioned above, the most accurate empirical relation to energy content is that based on organic carbon mass. However, such determinations are time-consuming and require expensive laboratory equipment (ignition furnace connected to IR analyser for $\mathrm{CO}_{2}$ detection). Furthermore, there are not many literature data available referring to $\mathrm{J} \cdot \mathrm{mg}^{-1} \mathrm{C}_{\text {org }}$. 
Determinations of energy content related to AFDW are less time-consuming and the equipment needed is simpler and cheaper. Additionally, there is a bulk of AFDW based energy content data in the literature (e.g., see Rumohr et al., 1987, and references therein). Therefore, we think that AFDW provides the best compromise in serving as a reference unit of body mass in relation to energy content.

The conversion factors $\left(\mathrm{J} \cdot \mathrm{AFDW}^{-1}\right.$ ) presented in Table I include seasonal, geographical, species-, and method-related deviations. They show a wide range with a maximum value $\left(30.6 \mathrm{~J} \cdot \mathrm{mg}^{-1}\right.$ AFDW), which is twice the minimum value (15.9 $\cdot \mathrm{mg}^{-1} \mathrm{AFDW}$ ) of all taxa. However, with respect to all taxa, the $95 \%$ confidence interval is only $\approx \pm 1.5 \%$ of the median. The confidence intervals for the different taxonomic groups are also small. Thus, these factors can be used as general factors when estimating the energy contents and flows in aquatic ecosystems.

The median value of all taxa included $\left(23.09+0.27,-0.30 \mathrm{~J} \cdot \mathrm{mg}^{-1}\right.$ AFDW $)$ and the corresponding mean $\left(22.99 \pm 0.26 \mathrm{~J} \cdot \mathrm{mg}^{-1}\right.$ AFDW) are practically identical. Hence, the average value for all taxa of macrobenthic invertebrates is $23 \mathrm{~J} \cdot \mathrm{mg}^{-1}$ AFDW.

This value is in the range of average energy content values given by other authors: $24.4 \mathrm{~J} \cdot \mathrm{mg}^{-1}$ AFDW (Slobodkin \& Richman, 1961), $23.2 \mathrm{~J} \cdot \mathrm{mg}^{-1}$ AFDW (Prus, 1970), $23.7 \mathrm{~J} \cdot \mathrm{mg}^{-1}$ AFDW (Salonen et al., 1976), $23.9 \mathrm{~J} \cdot \mathrm{mg}^{-1}$ AFDW (Norrbin \& Bămstedt, 1984), and $22.7 \mathrm{~J} \cdot \mathrm{mg}^{-1}$ AFDW (Wacasey \& Atkinson, 1987). With the exception of the latter, these factors are based also on pelagic or terrestrial animals. Therefore, they are slightly higher than our average value of $23 \mathrm{~J} \cdot \mathrm{mg}^{-1}$ AFDW, which refers only to macrobenthic invertebrates.

\section{ACKNOWLEDGEMENTS}

We gratefully acknowledge the permission of S. Hansson and L. E. Persson to use their unpublished data on energy content for this compilation.

\section{REFERENCES}

ANKAR, S. \& R. ELMGREN, 1978. The benthic macro- and meiofauna of the Askö-Landsort area (northern Baltic proper). A stratified random sampling survey. Contrib. Askö Lab. Univ. Stockh., No. 11, second corrected printing, $115 \mathrm{pp}$.

ARNTZ, W.E. \& D. BRUNSWIG, 1975. An approach to estimating the production of macrobenthos and demersal fish in a Western Baltic Abra alba community. Merentutkimuslaitoksen Julk. Havsforskningsinst. Skr., Vol. 239, pp. 195-205.

AtKinson, E.G. \& J.W. WACASEY, 1976. Caloric values of zoobenthos and phytobenthos from the Canadian Arctic. Dep. Environ. Fish. Mar. Serv. Tech. Rep., No. 632, 23 pp.

AtKInson, E.G. \& J.W. WACASEY, 1983. Caloric equivalents for benthic marine organisms from the Canadian Arctic. Can. Tech. Rep. Fish. Aquat. Sci., Vol. 1216, pp. 1-31.

BAST, H.-D. \& J.-A. vON OERTZEN, 1976. Zusammenstellung von Energieäquivalenten aquatischer Organismen unter besonderer Berücksichtigung der Ostsee. Teil 2. Wiss. Z. Univ. Rostock Math. Naturwiss. Reihe, Vol. 25, Heft 3. 
Brawn, V.M., D.L. Peer \& R.J. Bentley, 1968. Caloric content of the standing crop of benthic and epibenthic invertebrates of St. Magaret's Bay, Nova Scotia. J. Fish. Res. Board. Can., Vol. 25, pp. 1803-1811.

BRUNSwIG, D., 1973. Der Nahrungswert makrobenthischer Fischnährtiere der Kieler Bucht im Jahresgang. Diplom-Thesis, Kiel, F.R.G.

CASPERS, N., 1975. Kalorische Werte der dominierenden Invertebraten zweier Waldbäche des Naturparks Kottenforst-Wille. Arch. Hydrobiol., Vol. 75, pp. 484-489.

Chambers, M.R. \& H. Milne, 1979. Seasonal variation in the condition of some intertidal invertebrates of the Ythan estuary, Scotland. Estuarine Coastal Mar. Sci., Vol. 8, pp. 411-419.

CRISP, D.J., 1984. Energy flow measurements. In, Methods for the study of marine benthos, IBP Handbook, No. 16, edited by N.A. Holme \& A.D. McIntyre, Blackwell, Oxford, U.K., pp. 284-372.

Cummins, K.W. \& J.C. WUYCHFCK, 1971. Caloric equivalents for investigations in ecological energetics. Int. Assoc. Theoret. Appl. Limnol. Commun., No. 18, 158 pp.

Davis, J.P. \& J. G. WILSON, 1983. Seasonal changes in tissue weight and biochemical composition of the bivalve Nucula turgida in Dublin bay with reference to gametogenesis. Neth. J. Sea Res., Vol. 17, pp. 84-95.

FOBERG, M., 1976. Produktionsberăkningar fơr några makroevertebrater i Luleå skărgărd sommaren 1976. Zool. Inst. Univ. Stockh., Stockholm, Sweden.

GILBERT, M. A., 1973. Growth rate, longevity and maximum shell length of Macoma balthica (L.). Biol. Bull. (Woods Hole, Mass.), Vol. 145, pp. 119-126.

GrifFITHS, D., 1977. Caloric variation in crustacea and other animals. J. Anim. Ecol., Vol. 46, pp. 593-605.

GRONDEL, E., 1976. Qualitative und quantitative Untersuchungen an einem Ökosystem "Zostera-Wiese" vor Surendorf (Kieler Bucht, westliche Ostsee). Univ. Kiel SFB 95-Rep., No 18.

HAKALA, I., 1979. Seasonal variation in the carbon and energy contents and assimilation of a Mysis relicta population in Păäjärvi, southern Finland. Ann. Zool. Fenn., Vol. 16, pp. 129-137.

HugheS, R.H., 1970. An energy budget for a tidal flat population of the bivalve Scrobicularia plana (Da Costa). J. Anim. Ecol., Vol. 39, pp. 357-381.

KAUTSKY, N., 1981. Quantitative studies on gonad cycle, fecundity, reproductive output and recruitment in a Baltic Mytilus edulis L. population. Mar. Biol., Vol. 68, pp. 143-160.

KAY, D.G.\& A.E. BRAFIELD, 1973. The energy relations of the polychaete Neanthes (= Nereis) virens (Sars). J. Anim. Ecol., Vol. 42, pp. 673-692.

KREUTZBERG, M. \& J.-A. vON OERTZEN, 1973. Zusammenstellung von Energieåquivalenten aquatischer Organismen unter besonderer Berücksichtigung der Ostsee. Wiss. Z. Univ. Rostock Math. Naturwiss. Reihe, Vol. 22, Heft 10.

NORRBIN, F. \& U. BAMSTEDT, 1984. Energy contents in benthic and planktonic invertebrates of Kosterfjorden, Sweden. A comparison of energetic strategies in marine organism groups. Ophelia, Vol. 23, pp. 47-64.

ODUM, E.P., 1971. Fundamentals of ecology. W.B. Saunders Co., Philadelphia, Pennsylvania, third edition.

PAINE, R.T., 1964. Ash and caloric determinations of sponge and Ophistobranch tissues. Ecology, Vol. 45, pp. 384-387.

PAINE, R.T., 1965. Natural history limiting factors and energetics of the ophistobranch Navanax inermis. Ecology, Vol. 46, pp. 603-619.

Pruus, T., 1970. Calorific value of animals as an element of bioenergetical investigations. Pol. Arch. Hydrobiol., Vol. 17, pp. 183-199.

RaChor, E., K.H. MANTAU, W.E. ARnTz \& H. Rumohr, 1982. Seasonal and long-term population fluctuations in Diastylis rathkei (Crustacea, Cumacea) of Kiel Bay and German Bight. Neth. J. Sea Res., Vol. 16, pp. 141-150.

RUMOHR, H., T. BREY \& S. ANKaR, 1987. A compilation of biometric conversion factors for benthic invertebrates of the Baltic Sea. Balt. Mar. Biol. Publ., No. 9, 56 pp.

SaCHS, L., 1978. Angewandte Statistik. Springer-Verlag, New York, New York, fifth edition, 552 pp.

Salonen, K., J. Sarvala, I. Hakala \& M.-L. Viljanen, 1976. The relation of energy and organic content in aquatic invertebrates. Limnol. Oceanogr., Vol. 21, pp. 724-730.

Slobodkin, L. B. \& S. RichmaN, 1961. Calories/g in species of animals. Nature (London), Vol. 191, p. 299.

SuThERLAND, J.P., 1972. Energetics of high and low populations of the limpet, Acmaea scabra (Gould). Ecology, Vol. 53, pp. 431-437.

Thayer, G. W., W. E. Schaaf, J. W. Angelovic \& M. W. LaCroix, 1973. Caloric measurements of some estuarine organisms. Fish. Bull. NOAA, Vol. 71, pp. 289-296.

TYler, A. V., 1973. Caloric values of some North Atlantic invertebrates. Mar. Biol., Vol. 19, pp. $258-261$. W ACASEY, J. W. \& E. G. ATKINSON, 1987. Energy values of marine benthic invertebrates from the Canadian Arctic. Mar. Ecol. Prog. Ser., Vol. 39, pp. 243-250. 